\title{
Climatology of Frequency, Life Period, Energy and Speed for Tropical Disturbances and Cyclones over the Bay of Bengal
}

\author{
Saurav Dey Shuvo \\ Department of Meteorology, University of Dhaka, Dhaka, Bangladesh \\ Manuscript received: 20 April 2021; accepted for publication: 30 August 2021
}

\begin{abstract}
Tropical disturbances and cyclones are regularly formed at the Bay of Bengal basin. There are some common traits in them, albeit each one of them is unique. Discerning climatology for the basic features of any tropical cyclone is useful in numerous ways. This research has attempted to find a climatology for frequency, life period, energy, and speed for the tropical cyclones formed at the Bay of Bengal over a period of 31 years - from 1990 to 2020. The results elicit that there are marked changes in these aforementioned features. The total frequency, accumulated duration, and combined energy have escalated over the years. To be precise, these changes have taken effect more rigorously for the Post-monsoonal tropical cyclones. The overall translational speed has slightly diminished in recent years, except for the translational speed of cyclones formed during Pre-monsoon. These changes will have major ramifications on the lives and livelihoods of people, more so for those living in coastal areas. Hence, necessary actions are required to cut the probable losses and damages.
\end{abstract}

Keywords: Tropical cyclones, Bay of Bengal, Frequency, Velocity flux, Translational speed

\section{INTRODUCTION}

The Bay of Bengal, located between latitudes of $5^{\circ}$ North and $22^{\circ}$ North and longitudes of $80^{\circ}$ East and $100^{\circ}$ East, is a northward extension of the Indian Ocean (Sahoo and Bhaskaran, 2016; Shamsad et al., 2013). This Bay is bounded in the west by the eastern coast of Sri Lanka and India; on the north by the deltaic region of the Ganges-Brahmaputra-Meghna river system, and to the east by the Myanmar peninsula extending towards the Andaman-Nicobar ridges (Figure 1). The Bay covers an estimated area of about 2.2 million square kilometers $(\mathrm{km})$ and the average depth is 2,600 meters $(\mathrm{m})$ with a maximum depth of 5,258 m (Kusche et al., 2016).

The Bay of Bengal is one of the most active basins in the world regarding cyclonic activities (Alam and Dominey-Howes, 2015). Each year, at different seasons, the basin experiences at least one cyclonic disturbance (Ramsay, 2017). Each of them differs in lifecycle or intensity or direction of movement (Ankur et al., 2020; Balaguru et al., 2014; Kotal et al., 2009). No two events are similar (Mishra et al., 2020). However, there are some inherent characteristic patterns of tropical cyclones formed at

Corresponding author: Saurav Dey Shuvo

Email: sauravshuvo@du.ac.bd

DOI: https://doi.org/10.3329/dujees.v10i1.56277 the Bay of Bengal (Bhardwaj and Singh, 2020; Felton et al., 2013). Mostly, there are seasonal trends within these tropical cyclones (Girishkumar et al., 2015; Vissa et al., 2013). Besides, there is a school of thought that - there are changes in these trends with climate change (Emanuel, 2005).

Tropical cyclones are associated with heavy death tolls and severe economic loss to the affected nation (Nayak and Bhaskaran, 2014). Therefore, studying the climatology of tropical cyclones is of paramount importance for reducing the risk and damages associated with a cyclone. Forecasting a tropical cyclone has become easier with the advancement of technology (Anandh et al., 2020; Vijaya Kumari et al., 2019; Mohanty et al., 2010; Flather, 1994). Yet, there are scopes for improvement in management activities before and after a cyclone (Yesubabu et al., 2020; Mohanty, 1994).

The features of tropical cyclones are somewhat related to the season of their formation. The frequency, intensity, and movement of tropical cyclones differ from season to season (Busireddy et al., 2019). Therefore, clear know-how about these properties is mandatory to the forecasters as well as the personnel responsible for disaster management and cyclone preparedness. Loss of lives and wealth can be reduced upon assessing the nature of cyclones well ahead of their landfall. Bangladesh, having a developing economy, can benefit from this alleviation of constant losses due to frequent tropical cyclones 
forming over the Bay of Bengal almost every other year. Climatological analyses are useful for these purposes. Therefore, the objective of this research is to assess the intrinsic properties of tropical cyclones for a longer period to decipher the climatology for these properties. Tropical cyclones formed over the Bay of Bengal from 1990 to 2020 are being considered in this research.

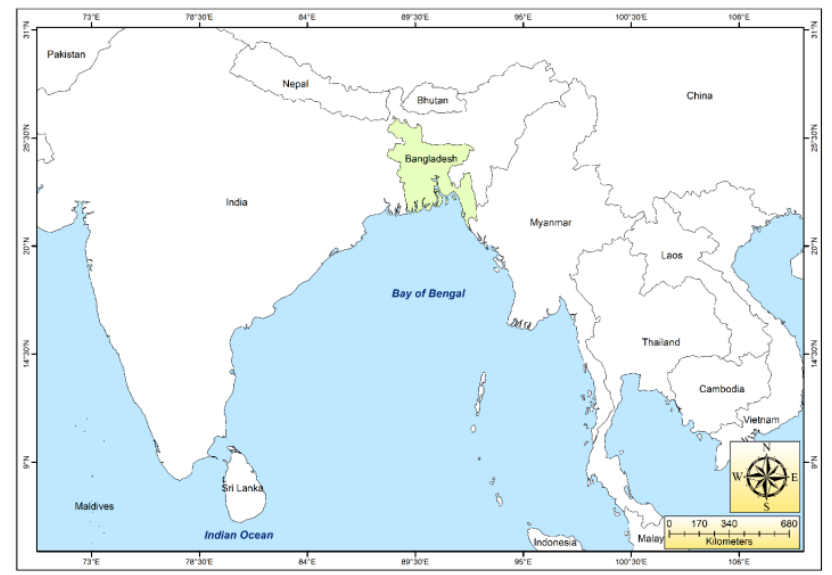

Figure 1: Location of the Bay of Bengal and its Surrounding Countries

\section{DATA AND METHODOLOGY}

Regional Specialized Meteorological Centre (RSMC) stores all relevant data for tropical cyclones that form over the North Indian Ocean (NIO), Arabian Sea (AS), and Bay of Bengal (BoB). All these data are freely available at https://rsmcnewdelhi.imd.gov.in/. For this research frequency data (Singh, 2007) from cyclones and disturbances, life period data, tropical cyclone energy matrix (Mohapatra and Vijay Kumar, 2017) data, and translational speed (Zhang et al., 2020; Mei et al., 2012) data have been collected from RSMC's website. Data for all the parameters have been collected for 31 years; from 1990 to 2020. Both annual data and seasonal data for all the parameters have been utilized in this research. For ease of analysis, the total length of this data has been divided into 03 decades for some parameters in this research. The $1^{\text {st }}$ decade includes data from 1990 to 1999; the $2^{\text {nd }}$ decade extends from 2000 to 2009 , and the third decade stretches from 2010 to 2020.

The frequency data for tropical disturbances and cyclones have been analyzed from the distinction of categories for tropical disturbances; which are also given by RSMC along with the data. Data have been analyzed from a seasonal perspective for this parameter. It should be noted that RSMC has segregated each year into 04 seasons; which are Premonsoon (March to May), Monsoon (June to September), Post-monsoon (October to December), and winter (January and February). Similar to analyses of frequency data, the life cycle data for tropical disturbances and cyclones (at different stages) have been assessed seasonally. The Tropical Cyclone Energy Matrix data at RSMC consists of data for Velocity Flux (VF), Accumulated Cyclone Energy (ACE), and Power Dissipation Index (PDI) of cyclonic disturbances (depression and above) as well as tropical cyclones (cyclonic storm and above) for different seasons and also the year as a whole. However, the data for only tropical cyclones have been evaluated in this research. Finally, average translational speed data for the Bay of Bengal basin have also been scrutinized for this research. The speed data is available for 06 hours, 12 hours, and 24 hours levels. The seasonal variations have been focused on delineating the climatology for both energy matrix data and translational speed data.

\section{DISTRIBUTION OF FREQUENCY DATA FOR CYCLONIC DISTURBANCES}

The distribution for different stages of Cyclonic Disturbances namely Cyclonic Depressions (maximum wind speed of 17 Knots or more), Cyclonic Storms (maximum wind speed of 34 Knots or more), and Severe Cyclones (maximum wind speed of 48 Knots or more) - over the Bay of Bengal have been given in Figure 2. More details about these classifications are available on RSMC's website. It is easy to understand from the figure that - the highest number of cyclonic activities have taken place during the Post-monsoon season. Also, depressions have formed mostly during the Monsoon while cyclones have formed during both Pre-monsoon and Postmonsoon seasons (Table 1a). Winter has been completely devoid of any severe cyclones, but depressions and storms have formed since 1999.

But notable findings have been revealed upon analyzing the data from a decadal perspective (Table 1b). During the $1^{\text {st }}$ decade (1990 to 1999), there have been more depressions and severe storms than that of the other two decades. All the years of that decade, have experiences at least one severe cyclonic storm. 
However, the maximum number of severe cyclonic storms (4) have been observed in 2013. It is clear from the distribution that - the Bay of Bengal has been very active since 2012 (which falls within the $3^{\text {rd }}$ decade). The $2^{\text {nd }}$ decade (2000 to 2009) has the least number of Severe Cyclones, but there is a considerable number of Depressions and Cyclonic Storms (Table 1b).
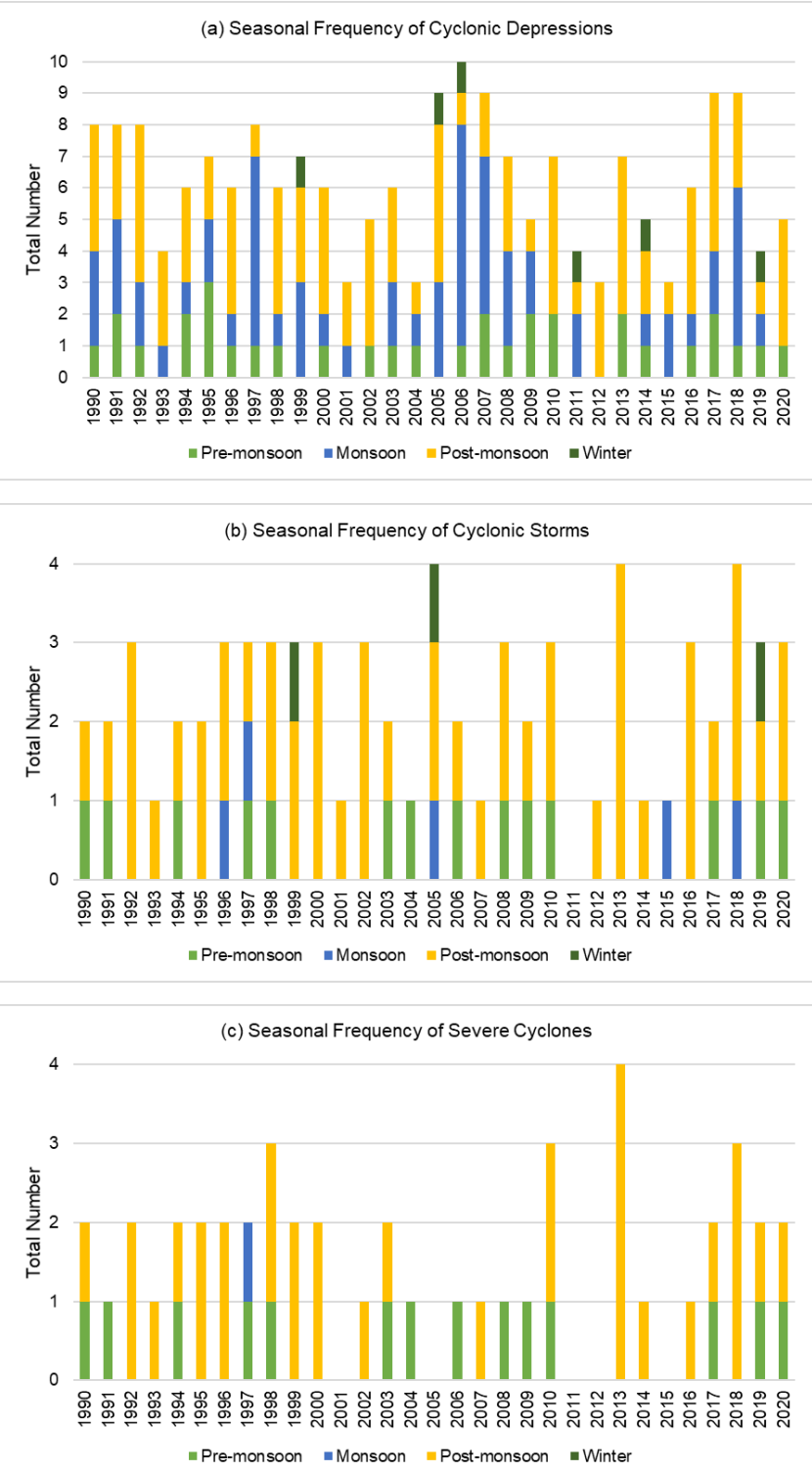

Figure 2: Seasonal Distributions of (a) Cyclonic Depressions; (b) Cyclonic Storms; and (c) Severe Cyclones over the Bay of Bengal for each year from 1990 to 2020. The Bar Diagram Represents the Total Number of Cyclonic Disturbances (at different stages; which are again shown in separate colors) Formed at Different Seasons of a Year
Table 1: Distributions of Cyclonic Activities over Bay of Bengal during 1990 to 2020

\begin{tabular}{|l|c|c|c|}
\hline & $\begin{array}{c}\text { Total } \\
\text { Cyclonic } \\
\text { Depressions }\end{array}$ & $\begin{array}{c}\text { Total } \\
\text { Cyclonic } \\
\text { Storms }\end{array}$ & $\begin{array}{c}\text { Total } \\
\text { Severe } \\
\text { Cyclones }\end{array}$ \\
\hline \multicolumn{3}{|c|}{ (a) seasonal distribution } \\
\hline $\begin{array}{l}\text { Pre-monsoon } \\
\text { Season }\end{array}$ & 33 & 14 & 14 \\
\hline Monsoon Season & 62 & 5 & 1 \\
\hline $\begin{array}{l}\text { Post-monsoon } \\
\text { Season }\end{array}$ & 92 & 49 & 32 \\
\hline Winter Season & 6 & 3 & 0 \\
\hline \multicolumn{2}{|c|}{ (b) decadal distribution } \\
\hline $\begin{array}{l}1^{\text {st }} \text { Decade } \\
(1990-1999)\end{array}$ & 68 & 24 & 19 \\
\hline $\begin{array}{l}2^{\text {nd }} \text { Decade } \\
(2000-2009)\end{array}$ & 63 & 22 & 10 \\
\hline $\begin{array}{l}3^{\text {rd }} \text { Decade } \\
(2010-2020)\end{array}$ & 62 & 25 & 18 \\
\hline
\end{tabular}

\section{DISTRIBUTION OF LIFE PERIOD DATA FOR CYCLONIC DISTURBANCES}

Life period data (in hours) for different stages of cyclonic disturbances formed over the Bay of Bengal during 1990 and 2020 have been illustrated in Figure 3. The stages of a cyclonic disturbance include Depressions (D) with Maximum Sustained surface Windspeed (MSW) of 17 to 27 Knots, Deep Depressions (DD) with MSW of 28 to 33 Knots, Cyclonic Storms (CS) with MSW of 34 to 47 Knots, Severe Cyclonic Storms (SCS) with MSW of 48 to 63 Knots, Very Severe Cyclonic Storms (VSCS) with MSW of 64 to 119 Knots and Super Cyclonic Storms (SuCS) with MSW of 120 Knots or more. There is also another category - Extremely Severe Cyclonic Storms, which has been merged with the category of VSCS. Further details are available at the website of RSMC.

The distributions have revealed some very interesting but concerning facts. There is an increasing tendency for the duration of cyclonic disturbances from the $1^{\text {st }}$ decade to the $3^{\text {rd }}$ decade (Table $2 b$ ). During the Pre-monsoon - there are similarities within the distributions for the duration of cyclonic disturbances, although the accumulated hour value is higher for the $3^{\text {rd }}$ decade. The accumulated duration during the Post-monsoon of the $3^{\text {rd }}$ decade has almost increased to 1.5 times that of the $1^{\text {st }}$ decade. Also, the accumulated duration for individual stages during the Post-monsoon has almost doubled than the accumulated duration during Monsoon and almost 
tripled than the accumulated duration during the Premonsoon. These details signify that tropical cyclones are having a longer lifespan with each decade. Another notable finding is the increase of duration for Cyclonic Storms and Very Severe Cyclonic Storms during the Pre-monsoon. This increment is more than that of Depressions and Deep Depressions (Table 2a). Monsoon and winter seasons, generally, don't have cyclonic activities; rather some occasional Depressions. There is a slight rise in Cyclonic Storms during the Post-monsoon, but not greater than Depressions and Deep Depressions.

Table 2: Distributions of Life Period (accumulated values in hours) for Cyclonic Disturbances Formed over the Bay of Bengal from 1990 to 2020

\begin{tabular}{|c|c|c|c|c|c|c|c|c|c|}
\hline Stage & \multicolumn{2}{|c|}{ Depressions } & \multicolumn{2}{|c|}{ Deep Depressions } & $\begin{array}{l}\text { Cyclonic } \\
\text { Storms }\end{array}$ & $\begin{array}{l}\text { Severe } \\
\text { Cyclonic } \\
\text { Storms }\end{array}$ & \multicolumn{2}{|c|}{$\begin{array}{l}\text { Very Severe } \\
\text { Cyclonic } \\
\text { Storms } \\
\end{array}$} & $\begin{array}{l}\text { Super } \\
\text { Cyclonic } \\
\text { Storms }\end{array}$ \\
\hline \multicolumn{10}{|c|}{ (a) seasonal distribution for individual stages } \\
\hline Pre-monsoon Season & \multicolumn{2}{|c|}{711} & \multicolumn{2}{|l|}{444} & 819 & 264 & \multicolumn{2}{|l|}{530} & 66 \\
\hline Monsoon Season & \multicolumn{2}{|c|}{2602} & \multicolumn{2}{|l|}{1470} & 183 & 6 & \multicolumn{2}{|l|}{0} & 0 \\
\hline Post-monsoon Season & \multicolumn{2}{|c|}{2992} & \multicolumn{2}{|l|}{1917} & 1675 & 665 & \multicolumn{2}{|l|}{729} & 69 \\
\hline Winter Season & \multicolumn{2}{|c|}{90} & \multicolumn{2}{|l|}{66} & 96 & 0 & \multicolumn{2}{|l|}{0} & 0 \\
\hline \multicolumn{10}{|c|}{ (b) decadal distribution for individual seasons } \\
\hline \multicolumn{2}{|l|}{ Season } & \multicolumn{2}{|c|}{ Pre-monsoon Season } & \multicolumn{2}{|c|}{ Monsoon Season } & \multicolumn{2}{|c|}{ Post-monsoon Season } & \multicolumn{2}{|c|}{ Winter Season } \\
\hline \multicolumn{2}{|c|}{ 1st Decade $(1990-1999)$} & \multicolumn{2}{|c|}{956} & \multicolumn{2}{|c|}{1803} & \multicolumn{2}{|l|}{2410} & \multicolumn{2}{|l|}{57} \\
\hline \multicolumn{2}{|l|}{$2^{\text {nd }}$ Decade $(2000-2009)$} & \multicolumn{2}{|l|}{906} & \multicolumn{2}{|c|}{1572} & \multicolumn{2}{|l|}{2211} & \multicolumn{2}{|l|}{96} \\
\hline \multicolumn{2}{|l|}{$3^{\text {rd }}$ Decade $(2010-2020)$} & \multicolumn{2}{|l|}{972} & \multicolumn{2}{|c|}{886} & \multicolumn{2}{|l|}{3426} & \multicolumn{2}{|l|}{99} \\
\hline
\end{tabular}

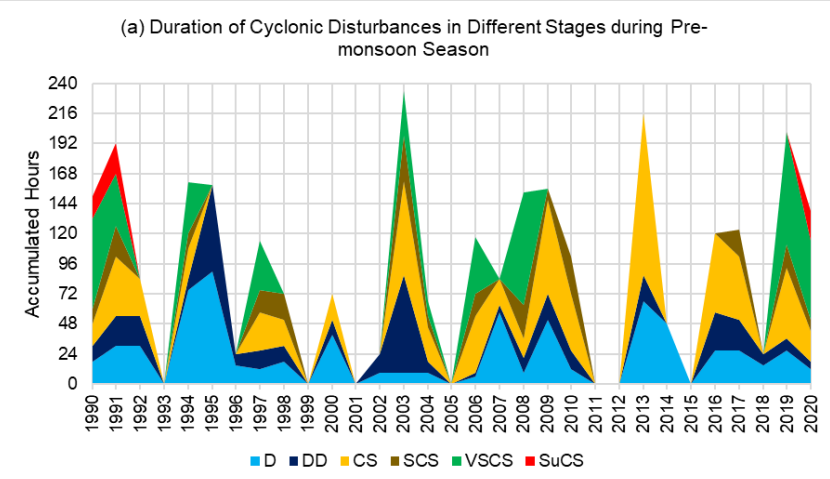

(b) Duration of Cyclonic Disturbances in Different Stages during Monsoon Season

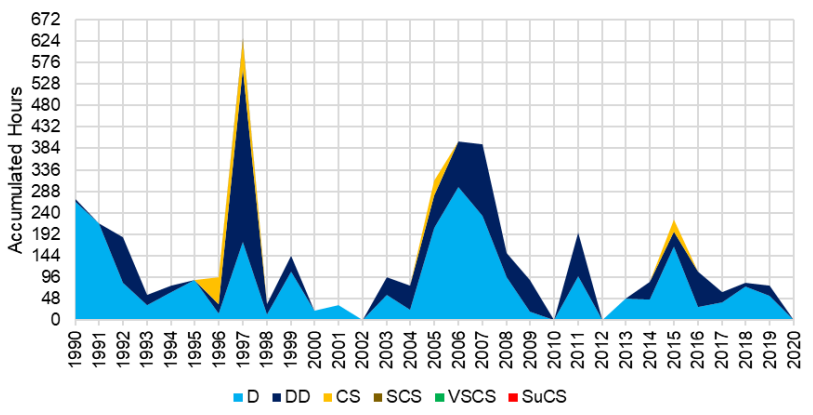

(c) Duration of Cyclonic Disturbances in Different Stages during Postmonsoon Season

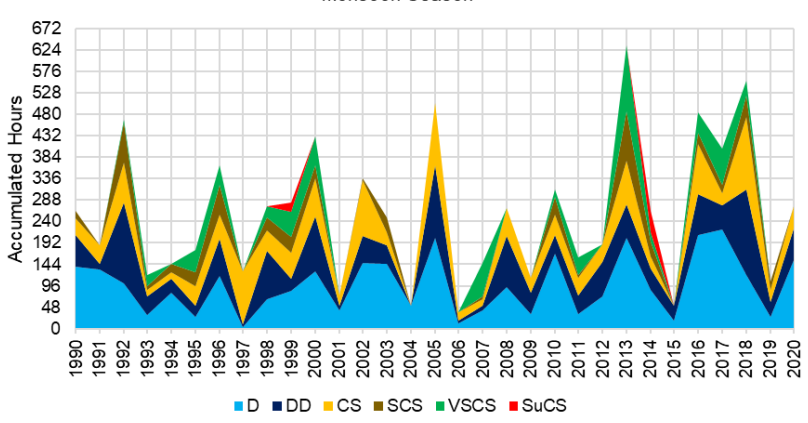

(d) Duration of Cyclonic Disturbances in Different Stages during Winte Season

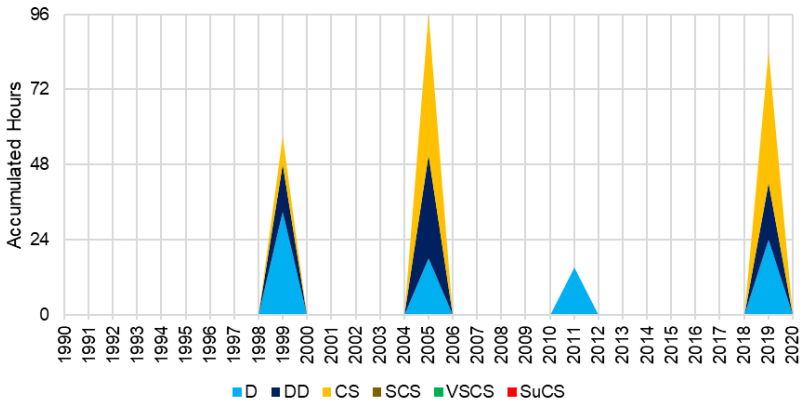

Figure 3: Seasonal Distribution of Tropical Disturbances (at different stages) Formed Over the Bay of Bengal from 1990 to 2020. Each Area Bar Shows Individual Stages Stacked Over One Another, Finally Revealing the Total Accumulated Hours of Cyclonic Disturbances 


\section{DISTRIBUTION OF TROPICAL CYCLONE ENERGY MATRIX DATA}

Distribution of Velocity Flux (VF), Accumulated Cyclone Energy (ACE) and Power Dissipation Index (PDI) for tropical cyclones (Cyclonic Storms and above) have been presented in Figure 4. It should be noted that these values are being averaged for all the cyclones over the Bay of Bengal for a whole year, consisting of Pre-monsoon, Monsoon, and Postmonsoon seasons. Again, to get the actual values ACE values are to be multiplied by $10^{4}$, and PDI values are too multiplied by $10^{5}$.
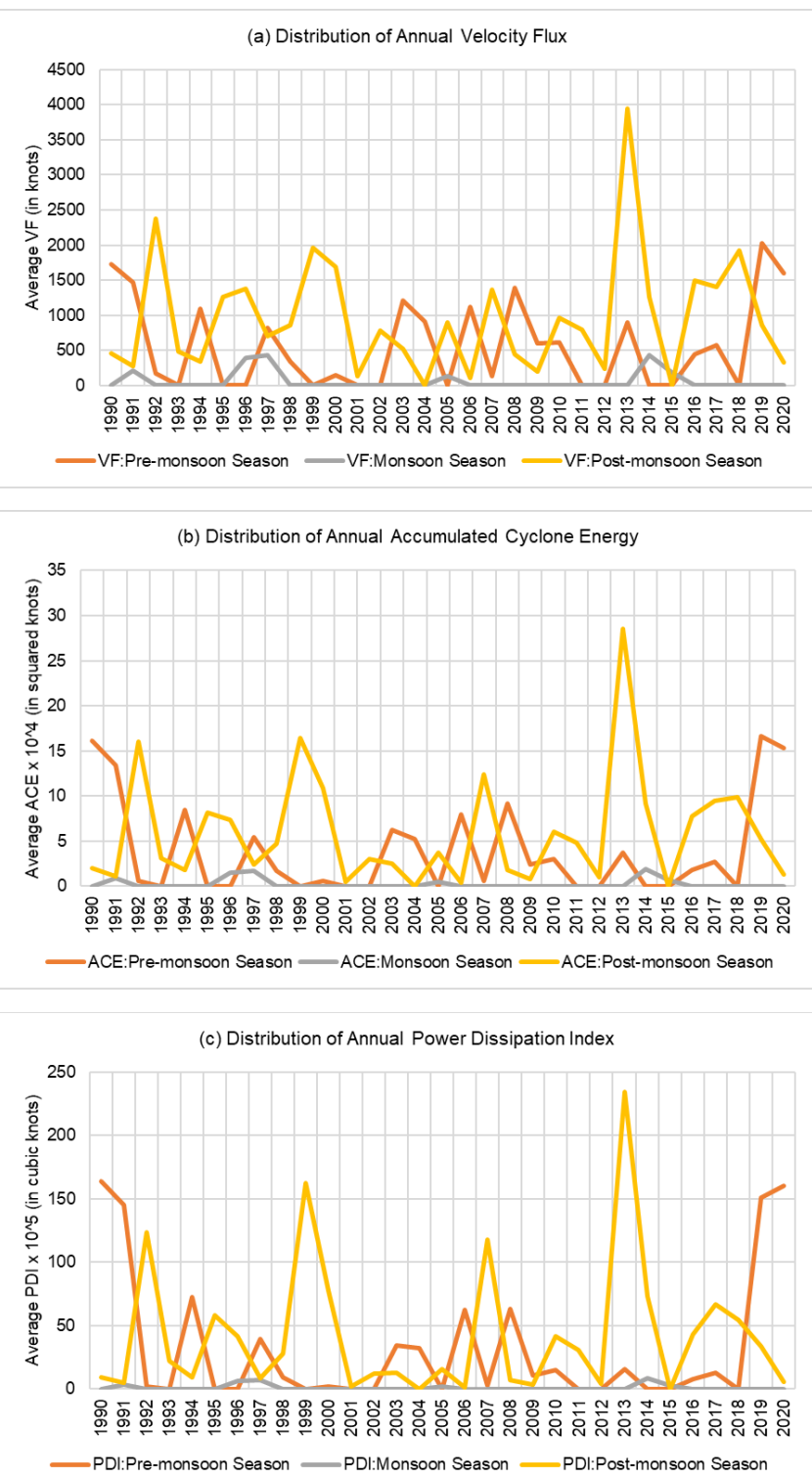

Figure 4: Distribution of Annual Average - (a) Velocity Flux; (b) Accumulated Cyclone Energy; (c) Power Dissipation Index for Tropical Cyclones Formed at the Bay of Bengal during 1990 to 2020
The distributions for all parameters of the energy matrix have close similarity to the distribution of life period for tropical disturbances. There is an increasing trend, especially during recent years (of $3^{\text {rd }}$ decade). The extent of increase for the 03 parameters is considerably large since they are averaged over a particular season for a year. The $2^{\text {nd }}$ decade (2000 to 2009) has the lowest values across the 03 decades for all three parameters. So, it is clear that - tropical cyclones over the Bay of Bengal are getting stronger. Apart from that, the seasonal distribution has identified that all VF, ACE, and PDI have greater values during the Post-monsoon season. Both ACE and PDI don't have many seasonal differences in their distributions. But the values of VF during the Postmonsoon are almost double to the VF during Premonsoon. Monsoon, understandably, have much lower values; as severe tropical cyclones are very uncommon during this season. Therefore, it can be said that stronger tropical cyclones occur during the Post-monsoon.

Table 3: Seasonal (a) and Decadal (b) Distributions of Parameters Available in Tropical Cyclone Energy Matrix Data

\begin{tabular}{|c|c|c|c|}
\hline & $\begin{array}{l}\text { Velocity } \\
\text { Flux (in } \\
\text { Knots) }\end{array}$ & $\begin{array}{l}\text { Accumulated } \\
\text { Cyclone } \\
\text { Energy (in x } \\
10^{4} \mathrm{Knots}^{2} \text { ) }\end{array}$ & $\begin{array}{l}\text { Power } \\
\text { Dissipation } \\
\text { Index (in x } \\
10^{5} \mathrm{Knots}^{3} \text { ) }\end{array}$ \\
\hline \multicolumn{4}{|c|}{ (a) seasonal distribution } \\
\hline $\begin{array}{l}\text { Pre- } \\
\text { monsoon } \\
\text { Season }\end{array}$ & 17317 & 121.2523 & 1001.08183 \\
\hline $\begin{array}{l}\text { Monsoon } \\
\text { Season }\end{array}$ & 1780 & 7.165 & 29.365 \\
\hline $\begin{array}{l}\text { Post- } \\
\text { monsoon } \\
\text { Season }\end{array}$ & 29448 & 182.5546 & 1303.12692 \\
\hline \multicolumn{4}{|c|}{ (b) decadal distribution } \\
\hline $\begin{array}{l}1^{\text {st }} \text { Decade } \\
(1990 \\
1999)\end{array}$ & 17177 & 112.8114 & 910.93528 \\
\hline $\begin{array}{l}2^{\text {nd }} \text { Decade } \\
(2000- \\
2009)\end{array}$ & 12118 & 68.0636 & 452.86722 \\
\hline $\begin{array}{l}3^{\text {rd }} \text { Decade } \\
(2010- \\
2020)\end{array}$ & 19985 & 128.9225 & 958.99625 \\
\hline
\end{tabular}




\section{DISTRIBUTION OF TRANSLATIONAL SPEED FOR CYCLONIC DISTURBANCES}

Translational speeds for cyclonic disturbances formed over the Bay of Bengal from 1990 to 2020 are given in Figure 5. The unit for this parameter is kilometers per hour (kmph). Again, the seasonal distributions have been assessed here. Also, the parameter is available at 06-hourly, 12-hourly, and 24hourly averages.

The seasonal distributions (Table 4a) of translational speed have some common features for all three seasons. Translational speed for tropical cyclones is at the highest for 06-hourly averages and is at the lowest for 24-hourly averages. But there are some noteworthy findings from decadal distribution. The translational speeds during the Pre-monsoon period (Table $4 \mathrm{~b}$ ) are at the highest during the $3^{\text {rd }}$ decade (2010 to 2020). A reverse trend (highest during $1^{\text {st }}$ decade, and lowest during $3^{\text {rd }}$ decade) to this has been observed for tropical cyclones of the Postmonsoon (Table 4d). Finally, the distribution during Monsoon (Table 4c) is different from the other distributions mentioned here. The highest values for 06-hourly and 12-hourly averages are found for the $2^{\text {nd }}$ decade while the highest for the 24-hourly averages are found for the $1^{\text {st }}$ decade. Therefore, the distributions demarcate that - tropical cyclones during Pre-monsoon have greater speed and tropical cyclones during Post-monsoon have less speed; during the recent years. And the combined values for all three averages have an overall decreasing trend from $1^{\text {st }}$ decade to $3^{\text {rd }}$ decade.
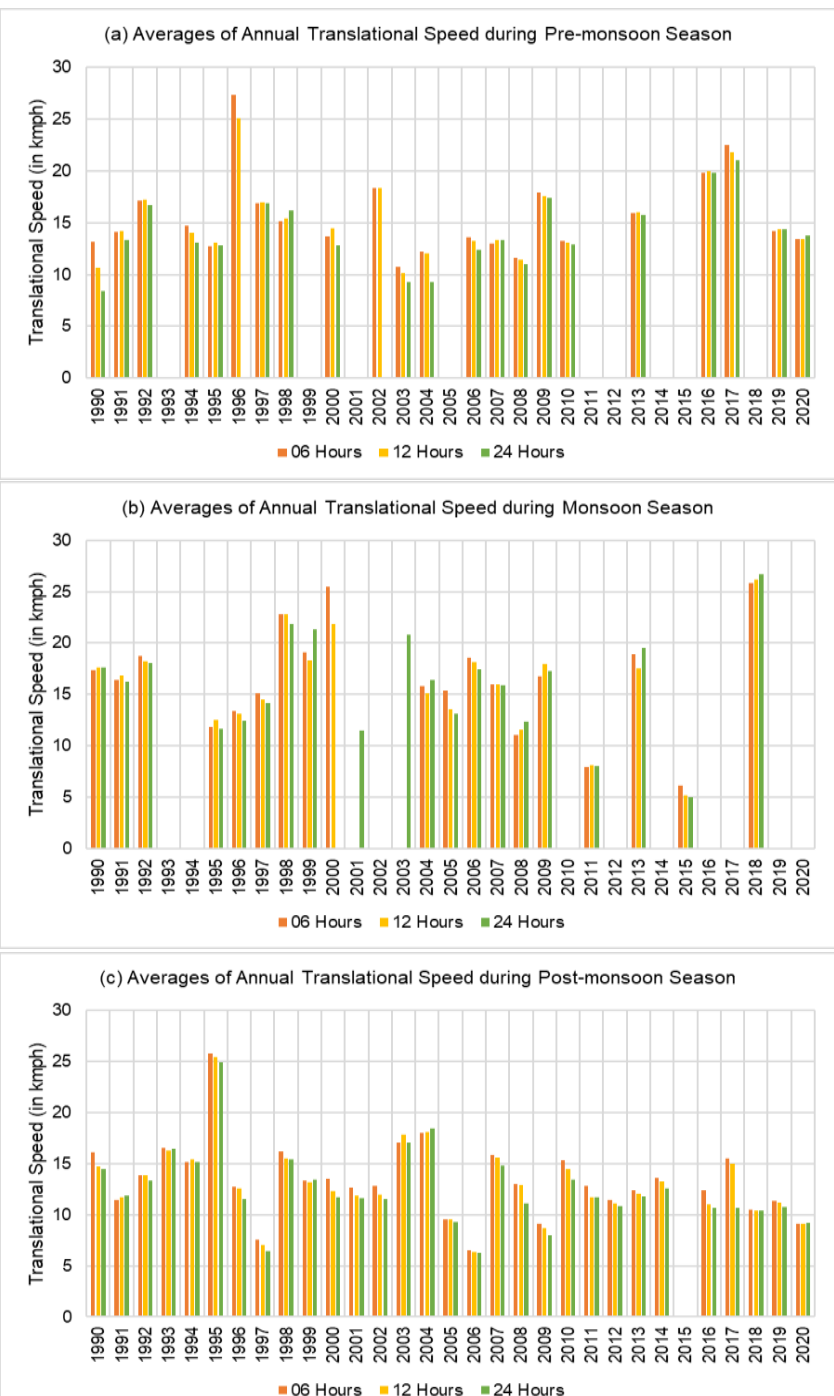

Figure 5: 06-hourly, 12-hourly, and 24-hourly Averages of Annual Translational Speed during (a) Pre-monsoon; (b) Monsoon; and (c) Post-monsoon Seasons for Cyclonic Disturbances over the Bay of Bengal.

Table 4: Seasonal $(a)$ and Decadal $(b-d)$ Distributions of Annual Translational Speed for 06-hourly, 12-hourly, and 24hourly Averages

\begin{tabular}{|c|c|c|c|}
\hline & 06-hourly averages & 12-hourly averages & 24-hourly averages \\
\hline \multicolumn{4}{|c|}{ (a) seasonal distribution for annual averages } \\
\hline Pre-monsoon Season & 15.52 & 15.26818182 & 14.028 \\
\hline Monsoon Season & 16.44894737 & 16.06157895 & 15.867 \\
\hline Post-monsoon Season & 13.381 & 13.01733333 & 12.50666667 \\
\hline \multicolumn{4}{|c|}{ (b) decadal distribution during Pre-monsoon season } \\
\hline $\begin{array}{l}\text { 1st Decade } \\
(1990-1999)\end{array}$ & 16.41125 & 15.83625 & 13.92714286 \\
\hline $\begin{array}{l}\text { 2nd Decade } \\
(2000-2009)\end{array}$ & 13.88125 & 13.8175 & 12.20571429 \\
\hline $\begin{array}{l}\text { 3rd Decade } \\
(2010-2020)\end{array}$ & 16.51666667 & 16.445 & 16.27166667 \\
\hline \multicolumn{4}{|c|}{ (c) decadal distribution during Monsoon season } \\
\hline 1st Decade & 16.8425 & 16.73375 & 16.6675 \\
\hline
\end{tabular}




\begin{tabular}{|l|l|l|l|}
\hline $\begin{array}{l}(1990-1999) \\
\begin{array}{l}\text { 2nd Decade } \\
(2000-2009)\end{array}\end{array}$ & 17.00857143 & 16.31142857 & 15.5975 \\
\hline $\begin{array}{l}\text { 3rd Decade } \\
(2010-2020)\end{array}$ & 14.6825 & 14.28 & 14.805 \\
\hline \begin{tabular}{l} 
(d) decadal distribution during Post-monsoon season \\
\hline $\begin{array}{l}1^{\text {st }} \text { Decade } \\
(1990-1999)\end{array}$
\end{tabular} & 14.871 & 14.594 & 14.312 \\
\hline $\begin{array}{l}2^{\text {nd }} \text { Decade } \\
(2000-2009)\end{array}$ & 12.82 & 12.523 & 11.991 \\
\hline $\begin{array}{l}3^{\text {rd }} \text { Decade } \\
(2010-2020)\end{array}$ & 12.452 & 11.935 & 11.217 \\
\hline
\end{tabular}

\section{DISCUSSION AND CONCLUSION}

Four specific data related to tropical disturbances over the Bay of Bengal have been assessed in this research. Distributions from the analyses depict a very alarming situation for this region.

There is a general tendency of increasing cyclonic disturbances over the Bay, especially the postmonsoonal cyclones. There have been significant cyclonic activities over the Bay during the 1990s. Then, a dip has been observed in the early 2000s; after which, the increase of severe cyclones has begun and continued up to recent years. This trend has been commonly found for all the distributions.

Along with the increase of cyclones during Postmonsoon, the average duration of the lifecycle for cyclonic disturbances has also expanded since 2010. This expansion of life period is considerably large in regards to the cyclones of pre-monsoon. To be precise, cyclonic storms (for both pre- and post-monsoon) and very severe cyclonic storms (for pre-monsoon only) have extended duration in recent years.

Cyclones of post-monsoon are becoming much stronger in recent years. This has been proved from a much higher VF value in Post-monsoon than that of Pre-monsoon and Monsoon seasons. Even the ACE and PDI values are both markedly higher in the Postmonsoon season.

In contrast - translational speed for Post-monsoon tropical cyclones is lower during recent years, although it is higher for Pre-monsoon cyclones. Overall, a decrease in translational speed has been identified between tropical cyclones of the 2010s to cyclones of the 1990s.

In short - tropical cyclones have mostly increased over the Bay of Bengal region. Their duration of existence over the Bay has also increased. Tropical cyclones have become substantially stronger, especially the Post-monsoon ones. But a modest decrease in their translational speed has also been perceived.

The outcomes from this research will benefit a variety of stakeholders; including - operational meteorologists from different meteorological agencies, personnel working in disaster risk reduction and management, policymakers, the scientific community studying climate change and its effect, and most the general people. Nonetheless, scopes of further research remain - especially by extending the study period - to get a deeper and inherent meaning from these distributions.

\section{REFERENCES}

Alam, E. and Dominey-Howes, D. (2015). A new catalogue of tropical cyclones of the northern Bay of Bengal and the distribution and effects of selected land alling events in Bangladesh. International Journal of Climatology, 35(6): 801-835. https://doi.org/ 10.1002/joc. 4035 .

Anandh, T. S., Das, B. K., Kuttippurath, J. and Chakraborty, A. (2020). A coupled model analyses on the interaction between oceanic eddies and tropical cyclones over the Bay of Bengal. Ocean Dynamics, 70(3): 327-337. https://doi.org/10.1007/s10236-01901330-x.

Ankur, K., Busireddy, N. K. R., Osuri, K. K. and Niyogi, D. (2020). On the relationship between intensity changes and rainfall distribution in tropical cyclones over the North Indian Ocean. International Journal of Climatology, 40 (4), 2015-2025. https://doi.org/ $10.1002 /$ joc. 6315 .

Balaguru, K., Taraphdar, S., Leung, L. R. and Foltz, G. R. (2014). Increase in the intensity of postmonsoon Bay of Bengal tropical cyclones. Geophysical Research 
Letters, 41(10), 3594-3601. https://doi.org/10.1002/ 2014GL060197.

Bhardwaj, P. and Singh, O. (2020). Climatological characteristics of Bay of Bengal tropical cyclones: 1972-2017. Theoretical and Applied Climatology, 139(1-2), 615-629. https://doi.org/10.1007/s00704019-02989-4.

Busireddy, N. K. R., Ankur, K., Osuri, K. K., Sivareddy, S. and Niyogi, D. (2019). The response of ocean parameters to tropical cyclones in the Bay of Bengal. Quarterly Journal of the Royal Meteorological Society, 145(724), 3320-3332. https://doi.org/10.1002/qj.3622.

Emanuel, K. (2005). Increasing destructiveness of tropical cyclones over the past 30 years. Nature, 436(7051), 686-688. https://doi.org/10.1038/nature03906.

Felton, C. S., Subrahmanyam, B. and Murty, V. S. N. (2013). ENSO-modulated cyclogenesis over the Bay of Bengal. Journal of Climate, 26(24), 9806-9818. https://doi.org/10.1175/JCLI-D-13-00134.1.

Flather, R. A. (1994). A Storm Surge Prediction Model for the Northern Bay of Bengal with Application to the Cyclone Disaster in April 1991. Journal of Physical Oceanography, 24, 172-190.

Girishkumar, M. S., Suprit, K., Vishnu, S., Prakash, V. P. T. and Ravichandran, M. (2015). The role of ENSO and MJO on rapid intensification of tropical cyclones in the Bay of Bengal during October-December. Theoretical and Applied Climatology, 120 (3-4): 797810. https://doi.org/ 10.1007 /s00704- 014- 1214-z.

Kotal, S. D., Kundu, P. K. and Roy Bhowmik, S. K. (2009). An analysis of sea surface temperature and maximum potential intensity of tropical cyclones over the Bay of Bengal between 1981 and 2000. Meteorological Applications, 16: 169-177. https:// doi. org/10.1002/ met.96.

Kusche, J., Uebbing, B., Rietbroek, R., Shum, C. K. and Khan, Z. H. (2016). Sea level budget in the Bay of Bengal (2002-2014) from GRACE and altimetry. Journal of Geophysical Research: Oceans: 121:11941217. https://doi.org/10.1002/2015JC011471.

Mei, W., Pasquero, C. and Primeau, F. (2012). The effect of translation speed upon the intensity of tropical cyclones over the tropical ocean. Geophysical Research Letters, 39(7): 1-6. https://doi.org/10.1029/2011GL050765.

Mishra, S. P., Sethi, K. C., Ojha, A. C. and Barik, K. K. (2020). Fani, an outlier among Pre-monsoon intraseasonal cyclones over Bay of Bengal. International Journal on Emerging Technologies, 11(2), 271-282.
Mohanty, U. C. (1994). Tropical cyclones in the Bay of Bengal and deterministic methods for prediction of their trajectories. Sadhana, 19(4): 567-582. https://doi.org/ 10.1007/ BF02835640.

Mohanty, U. C., Osuri, K. K., Routray, A., Mohapatra, M. abd Pattanayak, S. (2010). Simulation of Bay of Bengal Tropical Cyclones with WRF Model: Impact of Initial and Boundary Conditions. Marine Geodesy, 33(4): 294-314. https://doi.org/10.1080/ 01490419.2010.51 8061.

Mohapatra, M. and Vijay Kumar, V. (2017). Interannual variation of tropical cyclone energy metrics over North Indian Ocean. Climate Dynamics, 48(5-6): 1431-1445. https://doi.org/10.1007/s00382-016-3150-3.

Nayak, S. and Bhaskaran, P. K. (2014). Coastal vulnerability due to extreme waves at Kalpakkam based on historical tropical cyclones in the Bay of Bengal. International Journal of Climatology, 34 (5), 1460-1471. https://doi.org/10.1002/ joc. 3776.

Ramsay, H. (2017). The Global Climatology of Tropical Cyclones Tropical Cyclones. In Oxford Research Encyclopedias (pp. 1-35). https://doi.org/ https:// doi.org/ 10. 1093/ acrefore / 9780199389407.013. 79.

Sahoo, B. and Bhaskaran, P. K. (2016). Assessment on historical cyclone tracks in the Bay of Bengal, east coast of India. International Journal of Climatology, 36(1), 95-109. https://doi.org/10.1002/joc.4331.

Shamsad, M., Farukh, M., Chowdhury, M. and Basak, S. (2013). Sea Surface Temperature Anomaly in the Bay of Bengal in 2010. Journal of Environmental Science and Natural Resources, 5(2): 77-80. https://doi.org/ 10.3329/ jesnr.v5i2.14797.

Singh, O. P. (2007). Long-term trends in the frequency of severe cyclones of Bay of Bengal : Observations and simulations. Mausam, 58(1): 59-66. http://metnet.imd.gov. in/ mausamdocs/ 15816_F.pdf.

Vijaya Kumari, K., Karuna Sagar, S., Viswanadhapalli, Y., Dasari, H. P., \& Bhaskara Rao, S. V. (2019). Role of Planetary Boundary Layer Processes in the Simulation of Tropical Cyclones Over the Bay of Bengal. Pure and Applied Geophysics, 176 (2): 951-977. https://doi.org/ 10.1007/ s00024-018-2017-4.

Vissa, N. K., Satyanarayana, A. N. V. and Prasad Kumar, B. (2013). Intensity of tropical cyclones during preand post-monsoon seasons in relation to accumulated tropical cyclone heat potential over Bay of Bengal. Natural Hazards, 68 (2): 351-371. https:// doi.org/ 10.1007/ s11069-013-0625-y.

Yesubabu, V., Kattamanchi, V. K., Vissa, N. K., Dasari, H. P. and Sarangam, V. B. R. (2020). Impact of ocean 
mixed-layer depth initialization on the simulation of tropical cyclones over the Bay of Bengal using the WRF-ARW model. Meteorological Applications, 27(1), 1-18. https://doi.org/10.1002/met.1862.
Zhang, D., Zhang, H., Chen, D., Zheng, J., Cheng, X. and Tian, D. (2020). Changes in tropical-cyclone translation speed over the western north pacific. Atmosphere, 11(1). https://doi.org/10.3390/ atmos11010093. 